\title{
Antiedematogenic activity of the indole derivative N-salicyloyltryptamine in animal models
}

\author{
BENEDITO P. SOUSA-NETO ${ }^{1}$, BRUNO S. GOMES ${ }^{1}$, FRANCISCO V.M. CUNHA ${ }^{1}$, \\ DANIEL D.R. ARCANJO ${ }^{1,2}$, STANLEY J.C. GUTIERREZ ${ }^{3}$, MARIA F.V. SOUZA ${ }^{4}$, \\ FERNANDA R.C. ALMEIDA ${ }^{1,5}$ and FRANCISCO A. OLIVEIRA ${ }^{1,3}$
}
${ }^{1}$ Núcleo de Pesquisas em Plantas Medicinais, Universidade Federal do Piauí, Av. Universitária, s/n, Campus Ministro Petrônio Portella, SG-15, Ininga, 64049-550 Teresina, PI, Brazil
${ }^{2}$ Departamento de Biofísica e Fisiologia, Universidade Federal do Piauí, Av. Universitária, s/n, Campus Ministro Petrônio Portella, SG-08/09, Ininga, 64049-550 Teresina, PI, Brazil
${ }^{3}$ Coordenação do Curso de Farmácia, Universidade Federal do Piauí, Av. Universitária, s/n, Campus Ministro Petrônio Portella, Ininga, 64049-550 Teresina, PI, Brazil

${ }^{4}$ Programa de Pós-Graduação em Produtos Naturais e Sintéticos Bioativos, Departamento de Ciências Farmacêuticas, Centro de Ciências da Saúde, Universidade Federal da Paraíba, Campus I, Cidade Universitária, 58059-900 João Pessoa, PB, Brazil

${ }^{5}$ Departamento de Bioquímica e Farmacologia, Universidade Federal do Piauí, Av. Universitária, s/n, Campus Ministro Petrônio Portella, SG-08, Ininga, 64049-550 Teresina, PI, Brazil

Manuscript received on July 28, 2016; accepted for publication on January 3, 2017

\begin{abstract}
The N-salicyloyltryptamine (NST) is an indole derivative compound analogue to the alkaloid N-benzoyltryptamine. In the present study, the antiedematogenic activity of NST was investigated in animal models. Firstly, the acute toxicity for NST was assessed according to the OECD Guideline no. 423. The potential NST-induced antiedematogenic activity was evaluated by carrageenan-induced paw edema in rats, as well as by dextran-, compound 48/80-, histamine-, serotonin-, capsaicine-, and prostaglandin E2-induced paw edema in mice. The effect of NST on compound 48/80-induced ex vivo mast cell degranulation on mice mesenteric bed was investigated. No death or alteration of behavioral parameters was observed after administration of NST (2000 mg/kg, i.p.) during the observation time of 14 days. The NST (100 and $200 \mathrm{mg} / \mathrm{kg}$, i.p.) inhibited the carrageenan-induced edema from the 1 st to the 5 th hour $(* * p<0.01 ; * * * p<0.001)$. The edematogenic activity induced by dextran, compound $48 / 80$, histamine, serotonin, capsaicin, and prostaglandin E2 was inhibited by NST (100 mg/kg, i.p.) throughout the observation period $\left({ }^{*} p<0.01 ; *^{* *} p<0.001\right)$. The pretreatment with NST $(50,100$ or $200 \mathrm{mg} / \mathrm{kg}$, i.p) attenuates the compound $48 / 80$-induced mast cell degranulation $(* * p<0.01 ; * * *<0.001)$. Thus, the inhibition of both mast cell degranulation and release of endogenous mediators are probably involved in the NST-induced antiedematogenic effect.
\end{abstract}

Key words: Anti-inflammatory agents, edema, indoles, inflammation mediators, N-salicyloyltryptamine.

Correspondence to: Francisco de Assis Oliveira

E-mail: fassisol@ufpi.edu.br 


\section{INTRODUCTION}

Inflammation involves the participation of a wide sort of biological mediators, such as histamine, serotonin, bradykinin, and prostaglandins. These inflammatory agents promote vasodilation and neutrophil migration from blood towards inflamed tissues (Hajare et al. 2001). The interaction between the chemical mediators triggers a sequence of molecular events, and then resulting on the inflammatory process and development of pain (Déciga-Campos et al. 2007). The inflammatory response is defined as a normal reaction of living tissue to an injured area (Gautam and Jachak 2009). The lack of the recovery of the injured area increases the damage by formation of granulation tissue and accumulation of secretory cells (enzymes and free radicals), which positively increases the local inflammation, thus impairing the repair of damaged area (Dinarello 2010).

The drugs commonly used in the treatment of inflammation include the non-steroidal and steroidal anti-inflammatory drugs, which are able to promote several side effects, such as gastric ulcers, dyspepsia, bleeding and cardiovascular disorders (Dinarello 2010, Narum et al. 2014). Thus, the discovery of new drugs for the treatment of inflammatory diseases which present good therapeutic efficacy and fewer side effects is strongly necessary.

The indole core structure is part of one of the most natural and synthetic bioactive compounds (Sá-Alves et al. 2009), with important biological activities (Kaushik 2013) such as anti-inflammatory, antitumoral, analgesic, and antipyretic (Yadav and Romana 2013). Likewise, there are some indole derivative medicinal compounds usually applied in medical practices, such as: (1) ergometrine, which induces the contraction of the uterine musculature; (2) yohimbine, an alpha-2 adrenergic receptor antagonist; (3) reserpine, whose association with an diuretic is effective in preventing sodium retention and formation of edema (Schripsema et al. 2004).

Among the indole-based compounds, the benzoyltryptamines are related to the N-benzoyltryptamine named Guillaumin, which was previously isolated from Myrtopsis myrtoidea (Baill.), a plant from the Rutaceae family (Hifnawy et al. 1957). Other indole derivative compounds with psychotomimetic activity include $\mathrm{N}, \mathrm{N}$-dimethyltryptamine and 5-methoxy-N,Ndimethyltryptamine (Jiang et al. 2016, Shen et al. 2010) and N-salicyloyltryptamine (2-HydroxyN-[2-(1H-indol-3-yl)-ethyl]-benzamide (Fig. 1), which presents anticonvulsant, hypnotic and muscle relaxant activities (Oliveira et al. 2001). Furthermore, the N-salicyloyltryptamine (NST) promote an in vitro immunomodulatory response by decreasing the release of inflammatory mediators (Gasparotto et al. 2013). However, the in vivo potential of NST for the treatment of inflammatory diseases has not been investigated.

Therefore, the present study aims to investigate the antiedematogenic activity induced by N-salicyloyltryptamine (NST) in animal models of acute inflammation, as well as the possible mechanisms of action.

\section{MATERIALS AND METHODS}

\section{ANIMALS}

Male and female Wistar rats (180-210 g) and Swiss mice (25-30 g) were obtained from the Animal Facility of the Medicinal Plants Research Center of Federal University of Piauí (Teresina, PI, Brazil). The animals were kept in polypropylene cages, at the controlled temperature of $24 \pm 1{ }^{\circ} \mathrm{C}$, light/dark cycles of $12 \mathrm{~h}$, standard food (LabinaPurina ${ }^{\circledR}$, Nestlé, Brazil) and water ad libitum. For the experimental protocols, the animals were not previously fasted, and then were separated into groups of 6 animals $(n=6)$. After the experimental procedures, the animals were euthanized with 


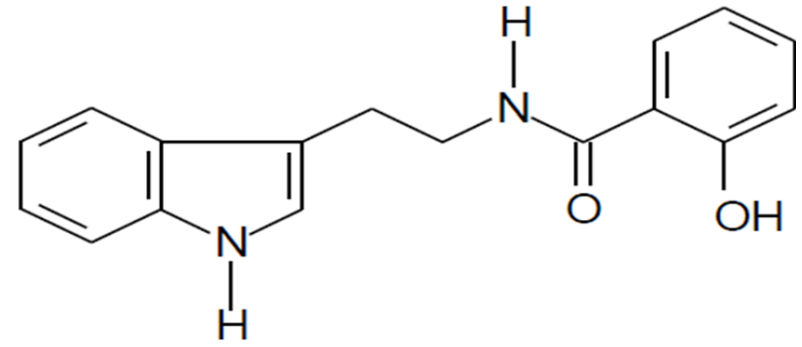

Figure 1 - Chemical structure of the N-salicyloyltryptamine (NST).

an overdose of sodium thiopental $(100 \mathrm{mg} /$ kg, i.p.), according to the Resolution No. 1000 (2012) from the Federal Council of Veterinary Medicine (CFMV), Brazil. The experimental protocols were previously approved by the Animal Experimentation Ethics Committee of the Federal University of Piauí (CEEA/UFPI, no. 082/14).

\section{DRUGS}

Carrageenan, dextran, compound 48/80, histamine, serotonin, prostaglandin E2, capsaicin, ketotifen, and Tween 80 were purchased from Sigma-Aldrich (St. Louis, MO, USA). Indomethacin (Indocid $®$ ) was purchased from Merck (Darmstadt, Germany). The NST was synthetized in the Laboratory of Pharmaceutical Chemistry of Federal University of Piauí (Teresina, PI, Brazil) under supervision of Prof. Stanley Juan Chávez Gutierrez, Ph.D. The choice of the doses of 50, 100 and $200 \mathrm{mg} /$ $\mathrm{kg}$ as well as the intraperitoneal route (i.p) for the experimental protocols were defined according Oliveira et al. (2001). The NST was diluted in $5.0 \%$ Tween 80 in saline solution $(0.9 \% \mathrm{NaCl})$, and administrated at the proportion of $0.1 \mathrm{ml} / 10 \mathrm{~g}$ of body weight.

\section{ACUTE TOXICOLOGICAL EVALUATION IN MICE}

The toxicological assessment was performed according to the OECD Guideline no. 423 (OECD 2002). Female Swiss mice were separated into groups of 3 animals, and then treated with NST at the dose of $2000 \mathrm{mg} / \mathrm{kg}$ (i.p.). Afterwards, the animals were submitted to clinical and behavioral observation during 8 hours during the first day of treatment. Afterwards, the animals were daily observed during $2 \mathrm{~h}$ in a period of 14 days.

INVESTIGATION OF NST EFFECT ON CARRAGEENAN-INDUCED PAW EDEMA IN RATS

Male and female Wistar rats were separated into five groups $(n=6)$. The animals were intraperitoneally pretreated with vehicle, NST $(50,100$, and 200 $\mathrm{mg} / \mathrm{kg}$, i.p.) or indomethacin $(10 \mathrm{mg} / \mathrm{kg})$. After $30 \mathrm{~min}$, carrageenan $(10 \mathrm{mg} / \mathrm{mL}, 0.1 \mathrm{~mL})$ was administrated in the right hind paw (subplantar region). The thickness of paws were recorded by a digital caliper (Pantec $\AA$ ) at different times $(1,2,3$, 4, 5 and 6 hours) after intraplantar administration of carrageenan. The edema was expressed as the difference between the final thickness ( $\mathrm{mm})$ and the initial thickness $(\mathrm{mm})$ of the paw (Winter et al. 1962). In order to carring out the next protocols of NST-induced antiedematogenic activity, the effective dose of $100 \mathrm{mg} / \mathrm{kg}$ was chosen.

INVESTIGATION OF NST EFFECT ON PAW EDEMA INDUCED BY DIFFERENT PHLOGISTIC AGENTS IN MICE

Initially, male and female Swiss mice were divided into 4 groups $(n=6)$, and pretreated (i.p.) with vehicle, NST $(100 \mathrm{mg} / \mathrm{kg})$ or indomethacin $(10 \mathrm{mg} /$ $\mathrm{kg})$. After $30 \mathrm{~min}, 50 \mu \mathrm{L}(1.0 \mathrm{mg} / \mathrm{mL})$ of dextran, compound 48/80, histamine, serotonin, capsaicin or prostaglandin E2 was administered in the right hind paw (i.pl.). The Sham group (untreated control group) was intraperitoneally treated with vehicle, and after $30 \mathrm{~min}, 50 \mu \mathrm{L}$ of sterile saline was administered by subplantar region. The thickness of paws was recorded by digital caliper (Pantec $®$ ) immediately before the administration of phlogistic agents $\left(\mathrm{t}_{0}\right)$, and each $30 \mathrm{~min}$ during $2 \mathrm{~h}$. The edema was expressed as the difference between the final thickness $(\mathrm{mm})$ and the initial thickness $(\mathrm{mm})$ of the paw (Winter et al. 1962). 
INVESTIGATION OF NST EFFECT ON THE $E X$ VIVO COMPOUND 48/80-INDUCED MAST CELL DEGRANULATION IN RATS

The animals were divided into 6 groups $(n=6)$, and then intraperitonally treated with vehicle, NST (50, 100 and $200 \mathrm{mg} / \mathrm{kg}$ ) or ketotifen $(2 \mathrm{mg} / \mathrm{kg})$. After $2 \mathrm{~h}$, the animals were euthanized, the mesenteric bed was removed and placed in tubes containing Ringer solution $(10 \mathrm{~mL})$. Afterwards, the mast cell degranulation was induced by incubating the mesenteric beds with $100 \mu \mathrm{L}$ of compound 48/80 $(0.4 \mu \mathrm{g} / \mathrm{mL})$. The Sham group was pretreated with vehicle, and the mesenteric beds were incubated with $100 \mu \mathrm{L}$ of distilled water instead of compound 48/80. After 30 minutes of incubation, the mesenteric beds were mounted on glass slides and stained with $0.1 \%$ toluidine blue. The intact and degranulated mast cells were counted by randomly choosing 10 fields of each slide. The results were expressed as percentage of degranulated mast cells (Norton 1954).

\section{STATISTICAL ANALYSES}

The results were expressed as mean \pm standard error of the mean (S.E.M.). The One-way ANOVA followed by Tukey's post-test was applied for comparison between groups with only one independent variable, and the Two-way ANOVA followed by Bonferroni post-test between groups with more than one independent variable. The level of significance was considered when ${ }^{*} p<0.05$. All statistical analyses were performed using Prism ${ }^{\circledR}$ version 6.01 software (GraphPad Software, San Diego, CA, USA).

\section{RESULTS}

\section{ACUTE TOXICOLOGICAL ASSESSMENT IN MICE}

The NST at the dose of $2000 \mathrm{mg} / \mathrm{kg}$ (i.p.) showed neither apparent signal of toxicity nor deaths of the animals after 14 days of observation. Therefore, the $\mathrm{DL}_{50}$ value was not possible to be determined.

\section{EFFECT OF NST ON CARRAGEENAN-INDUCED PAW EDEMA IN RATS}

The pretreatment of animals with NST (100 mg/ $\mathrm{kg}$, i.p.) significantly inhibited the by carrageenaninduced paw edema during the $1^{\text {st }}, 3^{\text {rd }}, 4^{\text {th }}$, and $5^{\text {th }}$ hour $\left({ }^{*} p<0.05\right)$, as well as during the $2^{\text {nd }}$ hour with higher level of significance $\left({ }^{* *} p<0.01\right)$, when compared with vehicle. Similarly, the pretreatment with NST (200 mg/kg, i.p.) also significantly decreased the formation of edema during the $1^{\text {st }}$ hour $\left({ }^{*} p<0.05\right)$, and the maximal inhibition was obtained from $2^{\text {nd }}$ to $5^{\text {th }}$ hour of observation $\left({ }^{* * *} p<0.001\right)$ when compared with vehicle. The indomethacin $(10 \mathrm{mg} /$ $\mathrm{kg}$, i.p.) significantly inhibited the formation of edema from the $1^{\text {st }}$ hour $\left({ }^{*} p<0.05\right)$, and remained until the $6^{\text {th }}$ hour $\left({ }^{* * *} p<0.001\right)$ when compared with vehicle. The NST at the dose of $50 \mathrm{mg} / \mathrm{kg}$ (i.p.) did not show significant inhibition of paw edema. Furthermore, any dose of NST inhibited the formation of edema at the $6^{\text {th }}$ hour (Fig. 2, Table I).

\section{EFFECT OF NST ON DEXTRAN-INDUCED PAW EDEMA IN MICE}

The administration of the NST at the dose of 100 $\mathrm{mg} / \mathrm{kg}$ (i.p.) decreased the formation of dextraninduced paw edema $(1 \mathrm{mg} / \mathrm{mL})$ in the right hind paw of mice. At 30, 60, 90, and $120 \mathrm{~min}$, the decrease of paw edema was observed by $\left.30 \%{ }^{* *} p<0.01\right), 38 \%$, $49 \%$, and $43.9 \%\left({ }^{* * *} p<0.001\right)$, respectively, when compared with vehicle. A significant inhibition of paw edema was also observed after treatment with indomethacin $(10 \mathrm{mg} / \mathrm{kg}$ ) by $57.02 \%, 48.4 \%, 58 \%$, and $72.22 \%$, respectively, when compared with vehicle (Fig. 3a).

\section{EFFECT OF NST ON COMPOUND 48/80-INDUCED PAW EDEMA IN MICE}

The treatment of mice with NST (100 mg/kg, i.p.) significantly decreased the formation of compound 
TABLE I

Effect of the NST (50, 100 e $200 \mathrm{mg} / \mathrm{kg}$, i.p.), vehicle ( $\mathrm{NaCl} 0.9 \%+5 \%$ Tween 80), and indomethacin (10 mg/kg i.p.) on carrageenan-induced paw edema in rats $(1 \%$; $0.1 \mathrm{~mL}$, i.pl.). The values are presented as mean $\pm \mathrm{SEM}$. * $p<0.05$, **p<0.01 and $* * p<0.001$ compared with vehicle group ( $\mathrm{NaCl} 0.9 \%+5 \%$ Tween 80$)$. Two-way ANOVA followed by Bonferroni's post-hoc test.

\begin{tabular}{|c|c|c|c|c|c|c|}
\hline \multirow{3}{*}{$\begin{array}{c}\text { Treatment } \\
\text { (mg/kg) }\end{array}$} & \multicolumn{6}{|c|}{ Paw edema (mm) } \\
\hline & \multicolumn{6}{|c|}{ Intervals (hours) } \\
\hline & $1 \mathrm{~h}$ & $2 \mathrm{~h}$ & $3 \mathrm{~h}$ & $4 \mathrm{~h}$ & $5 \mathrm{~h}$ & $6 \mathrm{~h}$ \\
\hline Vehicle & $1.63 \pm 0.12$ & $3.58 \pm 0.23$ & $3.76 \pm 0.16$ & $3.72 \pm 0.28$ & $3.71 \pm 0.26$ & $3.27 \pm 0.23$ \\
\hline NST (50) & $1.12 \pm 0.30$ & $2.88 \pm 0.25$ & $3.08 \pm 0.26$ & $2.96 \pm 0.09$ & $2.98 \pm 0.14$ & $2.62 \pm 0.16$ \\
\hline$\%$ & $-31,28$ & -19.55 & -18.08 & -20.43 & -19.67 & -19.87 \\
\hline NST (100) & $0.86 \pm 0.24^{*}$ & $2.03 \pm 0.35^{* *}$ & $2.93 \pm 0.23^{*}$ & $2.84 \pm 0.26^{*}$ & $3.07 \pm 0.26^{*}$ & $2.97 \pm 0.16$ \\
\hline$\%$ & -47.23 & -43.10 & $-22,43$ & -23.67 & -17.25 & -9.17 \\
\hline NST (200) & $0.80 \pm 0.13 *$ & $1.42 \pm 0.37 * * *$ & $1.97 \pm 0.43 * * *$ & $1.97 \pm 0.25 * * *$ & $2.36 \pm 0.24 * * *$ & $2.31 \pm 0.36$ \\
\hline$\%$ & -50.64 & -60.05 & -47.60 & -42.85 & -38.89 & -25.68 \\
\hline $\begin{array}{c}\text { Indomethacin } \\
\text { (10) }\end{array}$ & $0.91 \pm 0.05^{*}$ & $1.23 \pm 0.17^{* * *}$ & $1.18 \pm 0.18^{* * *}$ & $1.23 \pm 0.22 * * *$ & $1.62 \pm 0.17 * * *$ & $1.67 \pm 0.17 * * *$ \\
\hline$\%$ & -44.17 & -65.64 & -68.35 & -66.93 & -56.06 & -48.69 \\
\hline
\end{tabular}

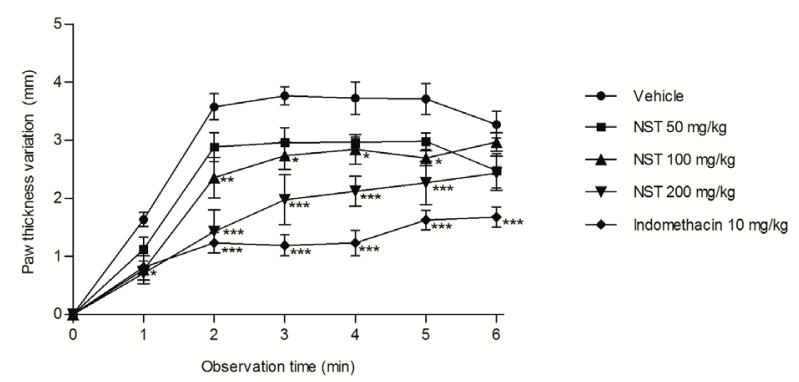

Figure 2 - Effect of the NST (50, 100 e $200 \mathrm{mg} / \mathrm{kg}$, i.p.), vehicle $(\mathrm{NaCl} 0.9 \%+5 \%$ Tween 80$)$, and indomethacin $(10 \mathrm{mg} / \mathrm{kg}$ i.p.) on carrageenan-induced paw edema in rats (1\%;0.1 $\mathrm{mL}$, i.pl.). The values are expressed as mean \pm SEM. ${ }^{*} p<0.05$, $* * p<0.01$ and $* * * p<0.001$ when compared with vehicle group. Two-way ANOVA followed by Bonferroni's post-hoc test.

48/80-induced paw edema ( $1 \mathrm{mg} / \mathrm{mL})$ by $46.6 \%$, $35.2 \%, 33.8 \%\left({ }^{* * *} p<0.001\right)$, and $43.9 \%\left({ }^{* *} p<0,01\right)$ of inhibition, observed after $30,60,90$, and 120 min, respectively, when compared with vehicle. A significant inhibition of paw edema from 30 to $120 \mathrm{~min}$ was also observed after treatment with indomethacin $(10 \mathrm{mg} / \mathrm{kg})$, by $59.3 \%, 46.4 \%, 42.9 \%$, and $45 \%\left({ }^{* * *} p<0.001\right)$ of inhibition, respectively (Fig. 3b).

\section{EFFECT OF NST ON HISTAMINE-INDUCED PAW EDEMA IN MICE}

Mice treated with NST $(100 \mathrm{mg} / \mathrm{kg})$ inhibited the formation of histamine-induced paw edema ( $1 \mathrm{mg} /$ $\mathrm{mL}$ ) from 30 to $90 \mathrm{~min}$, with $56.3 \%, 61.5 \%$, and $70.7 \%\left({ }^{* * *} p<0.001\right)$ of inhibition, respectively, when compared with vehicle. A significant reversion of edema by $52.7 \%, 57.6 \%$, and $60.9 \%$ was also observed during 30,60, and 90 minutes, respectively, for mice treated with indomethacin $(10 \mathrm{mg} / \mathrm{kg}$, i.p.), when compared with vehicle (Fig. 3c).

\section{EFFECT OF NST ON SEROTONIN-INDUCED PAW EDEMA IN MICE}

The treatment of mice with NST $(100 \mathrm{mg} / \mathrm{kg})$ reduced the formation of serotonin-induced paw edema $(1 \mathrm{mg} / \mathrm{mL})$ by $38.3 \%, 40.4 \%\left({ }^{*} p<0.05\right)$, and $60.4 \%\left({ }^{* *} p<0.01\right)$ at times of 30,60 , and 90 min, respectively, when compared with vehicle. A significant inhibition of edema by $65.5 \%, 59.5 \%$, 
and $62.5 \%\left({ }^{* * *} p<0.001\right)$ was observed in mice treated with indomethacin $(10 \mathrm{mg} / \mathrm{kg})$ during the first 90 minutes compared the vehicle group. However, any treatment was able to significantly reverse the formation of edema during the last hour of observation ( ${ }^{*} p>0.05$ ) (Fig. 3d).

\section{EFFECT OF NST ON CAPSAICIN-INDUCED PAW EDEMA IN MICE}

The NST at the dose of $100 \mathrm{mg} / \mathrm{kg}$ (i.p.) inhibited the formation of capsaicin-induced paw edema $(1 \mathrm{mg} / \mathrm{mL})$ at times of 30, 60 and 90 minutes by $51.9 \%\left({ }^{*} p<0.05\right), 67.3 \%\left({ }^{* * *} p<0.001\right)$, and $76.0 \%$ $\left({ }^{* *} p<0.01\right)$, respectively, when compared with vehicle. A significant reduction of edema by $67.5 \%$, $74.7 \%\left({ }^{* * *} p<0.001\right)$, and $71.8 \%\left({ }^{* * *} p<0.01\right)$ in mice treated with indomethacin $(10 \mathrm{mg} / \mathrm{kg})$ was also observed during the 30,60 and $90 \mathrm{~min}$, respectively (Fig. 3e).

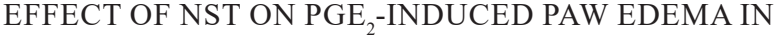 MICE}

Mice pretreated with NST at the dose of $100 \mathrm{mg} / \mathrm{kg}$ (i.p.) decreased the formation of $\mathrm{PGE}_{2}$-induced paw edema $(1 \mathrm{mg} / \mathrm{mL})$ by $58 \%, 65.7 \%\left({ }^{* * *} p<0.001\right)$, and $68.4 \%\left({ }^{*} p<0.05\right)$ at the 30,60 and $90 \mathrm{~min}$ of observation, respectively, when compared with vehicle. A significant reduction by $71.4 \%, 76.1 \%$ $\left.{ }^{* * *} p<0.001\right)$, and $71 \%\left({ }^{*} p<0.05\right)$ was also observed for the mice treated with indomethacin $(10 \mathrm{mg} /$ $\mathrm{kg}$, i.p.) during the times of 30,60 , and $90 \mathrm{~min}$, respectively (Fig. 3f).

\section{EFFECT OF NST ON COMPOUND 48/80-INDUCED $E X$ VIVO MAST CELL DEGRANULATION IN RATS}

The pretreatment of rats with NST at the dose of $50 \mathrm{mg} / \mathrm{kg}$ (i.p.) decrease significantly by $32 \%$ $\left({ }^{* *} p<0.01\right)$ the ex vivo mast cell degranulation induced by compound 48/80 $(0.4 \mu \mathrm{g} / \mathrm{ml})$ when compared with vehicle. Likewise, NST at doses of 100 and $200 \mathrm{mg} / \mathrm{kg}$ (i.p.) also significantly decreased the mast cells degranulation by $71.02 \%$, and
$70.85 \%\left({ }^{* * *} p<0.001\right)$, respectively, when compared with vehicle. The positive control ketotifen $(2 \mathrm{mg} /$ $\mathrm{kg}$, i.p.) inhibited the mast cell degranulation by $74.54 \%\left({ }^{* * *} p<0.001\right)$ when compared with vehicle. (Figs. 4 and 5).

\section{DISCUSSION}

The indole core structure is present in many natural substances mainly derived from plants (Williams 2001). The chemical structure of NST consists of an indole core related to the N-benzoyltryptamine, an indole alkaloid isolated from Myrtopsis myrtoidea (Baill) Guillaumin (Hifnawy 1957). Interestingly, reported that several indole derivative compounds are able to promote anti-inflammatory activities in different experimental models of paw edema induced by carrageenan, dextran, and histamine (Barbosa-Filho et al. 2006). However, any previous report related to the anti-inflammatory properties of NST was found in experimental models which reproduce an inflammatory response.

The paw edema induced by different phlogistic agents represents an experimental model of acute inflammation widely used in order to prospect new drugs with potential application in the treatment of inflammatory diseases (Fernandes et al. 2015). In this study, NST intraperitoneally administrated inhibited the carrageenan-induced edematogenic effect from the first to fifth hour of observation. These experiments were also performed by the oral route in the carrageenan-induced paw edema, but no anti-edematogenic effect was observed for the NST by this route (data not shown).

The carrageenan-induced inflammatory process involves two phases; the first phase is related to the release of histamine and serotonin from mast cells, while the late phase involves release of prostaglandin, production of cytokines, and intense neutrophil migration (Winter et al. 1962). During the initial phase of the inflammatory process, the released mediators act on vascular 

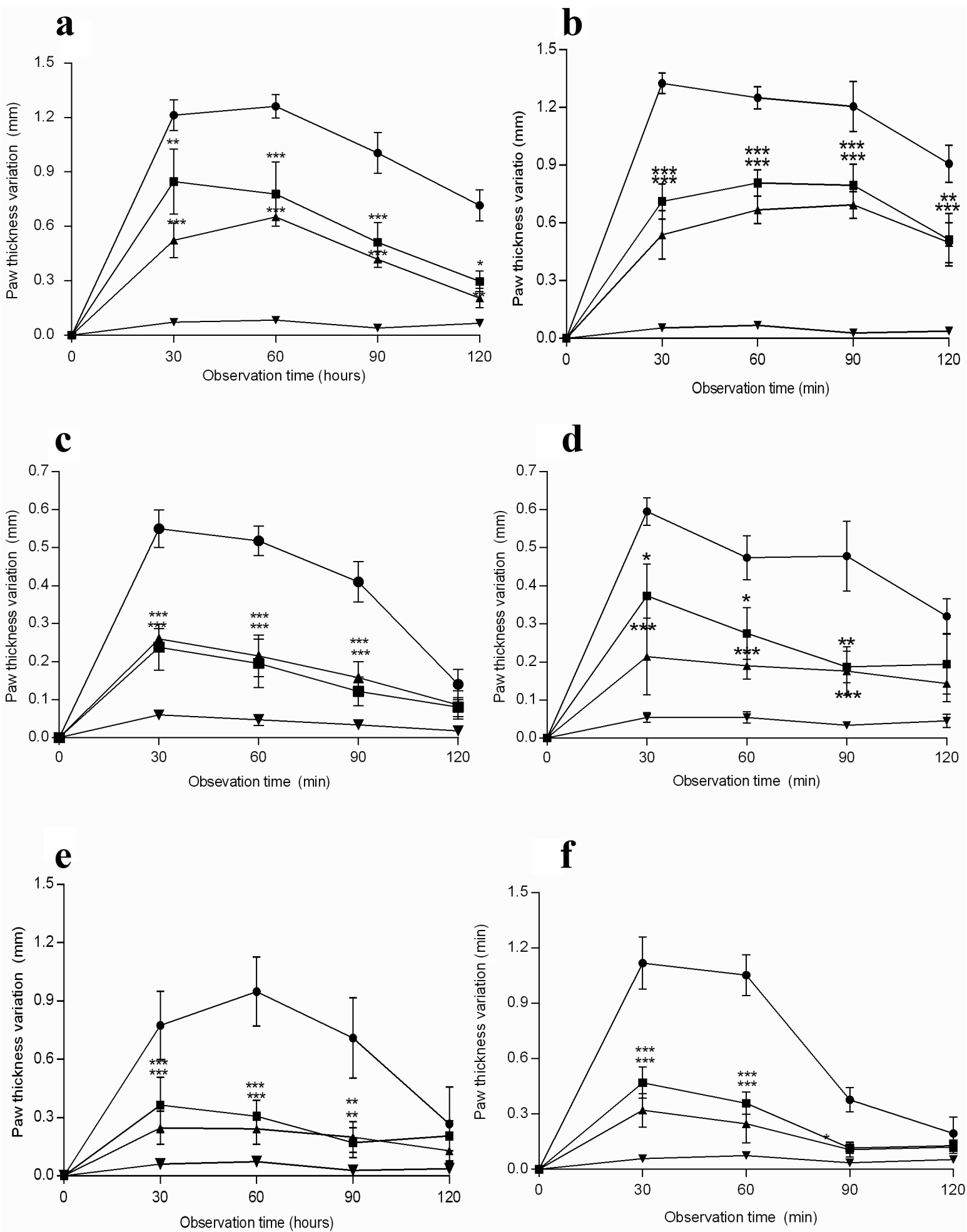

Figure 3 - Effect of the NST $(\bullet)$, vehicle $(\boldsymbol{\square})$ and indomethacin $(\boldsymbol{\Delta})$ on paw edema induced by different phlogistic agents $(1.0 \%$; $0.1 \mathrm{~mL}$, i.pl.) in mice, as follows: Dextran (a); Compound 48/80 (b); Histamine (c); Serotonin (d); Capsaicin (e); and Prostaglandin E2 (f). The sham group $(\boldsymbol{\nabla})$ was treated with vehicle and received only saline by intraplantar route. The values are expressed as mean \pm SEM. ${ }^{*} p<0.05,{ }^{* *} p<0.01$ and ${ }^{* * *} p<0.001$ when compared with vehicle group. Two-way ANOVA followed by Bonferroni's post-hoc test. 


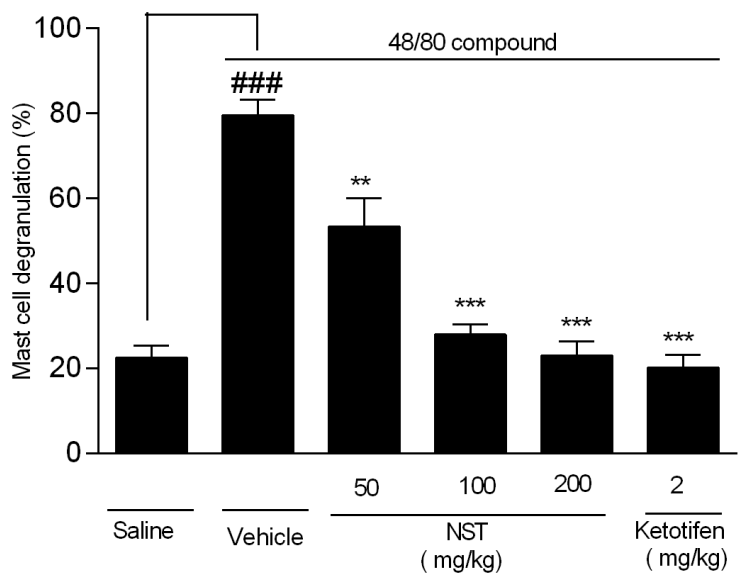

Figure 4 - Effect of the NST (50, 100 and $200 \mathrm{mg} / \mathrm{kg}$, i.p.), vehicle $(\mathrm{NaCl} 0.9 \%+5 \%$ Tween 80$)$, and cetotiphen $(2$ $\mathrm{mg} / \mathrm{kg}$ i.p.) on ex vivo compound 48/80-induced mast cell degranulation in rats. The values are presented as mean \pm SEM. ${ }^{* *} p<0.01$ and $* * * p<0.001$ when compared with vehicle group. One way ANOVA and Tukey's post-hoc test.

endothelium, and then promote leakage of fluid and proteins towards the inflammatory site (Di Rosa et al. 1971).

The NST decreased the formation of edema induced by histamine, serotonin, capsaicin and PGE2, suggesting the NST might prevent the release of endogenous mediators responsible for the formation of edema, considering that the inhibition of formation of edema was observed in the dextran- and compound 48/80-induced paw edema throughout the period of observation. These agents are able to induce mast cells degranulation, as well as promote release of vasoactive mediators, such as histamine and serotonin (Metcalfe 2008).

An antiedematogenic compound which has activity on the experimental paw edema models induced by different phlogistic agent usually acts on the the release of endogenous inflammatory mediators, such as histamine, serotonin, and bradykinin, as well as late mediators, such as inhibition of cyclooxygenase biosynthesis and, consequently, decreased expression of prostaglandins (Sadeghi et al. 2013). Several substances based on the indole core structure, such as caulerpin, oxepinamide, conicamin, and plakohypaphorine, are able to induce antiedematogenic activity on the paw edema induced by different phlogistic agents (Jaswir and Monsur 2011).

Interestingly, Gasparotto et al. (2013) previously demonstrated that NST inhibits the in vitro LPS-induced release of the inflammation mediators TNF- $\alpha$ e IL- $1 \beta$. The TNF- $\alpha$ is released by activated macrophages which triggers the proinflammatory cascade, increasing the production of reactive species as well as the expression and release of cytokines. The TNF- $\alpha$ acts synergistically with other cytokines, such as IFN- $\gamma$ and IL-17, promoting the pro-inflammatory state (Vendramini Costa and Carvalho 2012). In turn, the release of IL- $1 \beta$ by macrophages triggers inflammation and pain-related responses in different cell types. The expression of cyclooxygenase- 2 is induced by IL$1 \beta$ in cells of the central nervous system, which contributes to inflammatory pain hypersensitivity (Neeb et al. 2011). Thus, it is possible that the antinociceptive effect by NST previously observed (Quintans et al. 2010) may be related to the inhibition of IL- $1 \beta$.

The histamine and serotonin can be present on basophils and platelets, but the mast cells represent their main source, where they can be found in the mast cell granules. The release of these mediators is triggered as response of various stimuli (Sherwood and Toliver-Kinsky 2004). Therefore, the effect of NST on the compound 48/80-induced ex vivo mast cell degranulation was investigated. The mast cell degranulation occurs probably by a G-protein activation, which leads to the increased of IP3 concentration, whereby the release of intracellular calcium is promoted, resulting in the mast cell degranulation (Costa et al. 1998). In this study, NST demonstrated a possible membranestabilizing effect in these cells, then inhibiting 

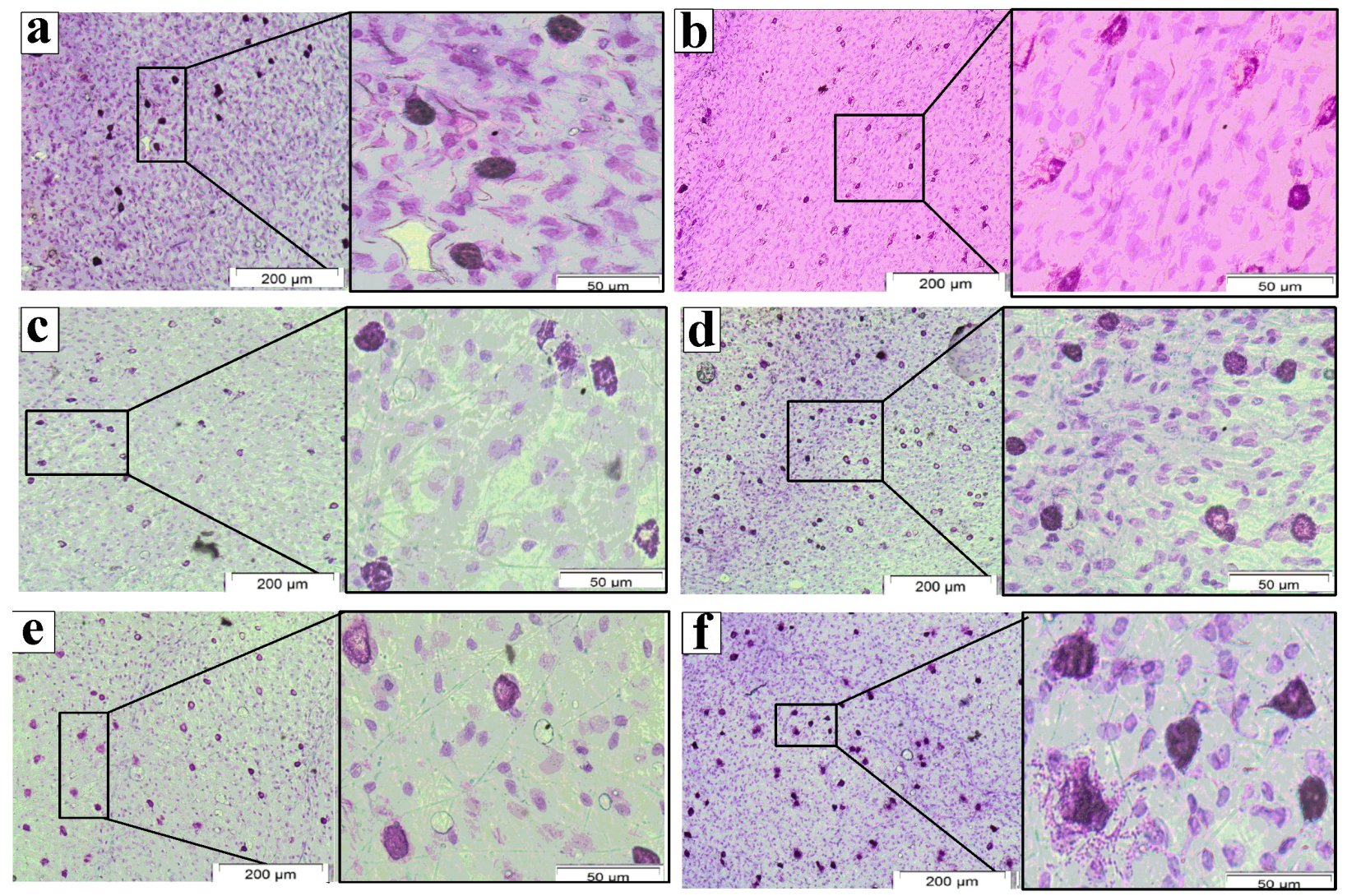

Figure 5 - Representative microphotography of the effect of the NST (50, 100 and $200 \mathrm{mg} / \mathrm{kg}$, i.p.), vehicle $(0.9 \% \mathrm{NaCl}+5 \%$ Tween 80, i.p.) and cetotiphen ( $2 \mathrm{mg} / \mathrm{kg}$, i.p.) on ex vivo compound $48 / 80$-induced mast cell degranulation in rats. Mast cells from rats treated with only vehicle (a), and treated with vehicle following the incubation with compound $48 / 80(0.4 \mu \mathrm{g} / \mathrm{mL})(\mathbf{b})$, exhibiting extensive mast cell degranulation. Mast cells from rats incubated with compound 48/80 and previously treated with the NST at doses of 50 (c), $100 \mathrm{mg} / \mathrm{kg}$ (d) and $200 \mathrm{mg} / \mathrm{kg}$ (e), and cetotiphen ( $2 \mathrm{mg} / \mathrm{kg})$ (f), showing inhibition of degranulation at the magnifications of $10 \times$ and $40 \times$.

the degranulation and release of inflammatory mediators.

In conclusion, the present study demonstrated that NST is able to decrease the formation of paw edema induced by different phlogistic agents, and the mast cells degranulation, which represent a sort of relevant experimental models of inflammation widely applied in the investigation of novel natural and synthetic products with therapeutic potential in the treatment of inflammatory diseases. Thus, the inhibition of release or action of mediators might be underlying the NST-induced anti-inflammatory effects.

\section{REFERENCES}

BARBOSA-FILHO JM, PIUVEZAM MR, MOURA MD, SILVA MS, LIMA KVB, LEITÃO-DA-CUNHA EV, FECHINE IM AND TAKEMURA OS. 2006. Antiinflammatory activity of alkaloids: A twenty-century review. Rev Bras Farmacogn 16: 109-139.

COSTA JJ, WELLER DF AND GALLI SJ. 1998. As células da resposta alérgica: mastócitos, basófilos e eosinófilos. JAMA Brasil 2: 268-278.

DÉCIGA-CAMPOS M, RIVERO-CRUZ I, ARRIAGAALBA M, CASTAÑEDA-CORRAL G, ANGELESLÓPEZ GE, NAVARRETE A AND MATA R. 2007. Acute toxicity and mutagenic activity of Mexican plants used in traditional medicine. J Ethnopharmacol 110: 334-342.

DI ROSA M, GIROUD JP AND WILLOUGHBY DA. 1971. Studies on the mediators of the acute inflammatory 
response induced in rats in different sites by carrageenan and turpentine. J Pathol 104: 15-29.

DINARELLO CA. 2010. Anti-inflamatory Agents: Present and Future. Cell. 140: 935-950.

FERNANDES HB ET AL. 2015. Laticifer proteins from Plumeria pudica inhibit the inflammatory and nociceptive responses by decreasing the action of inflammatory mediators and pro-inflammatory cytokines. Rev Bras Farmacogn 25: 269-277.

GASPAROTTO J ET AL. 2013. Effect of $\mathrm{N}$-salicyloyltryptamine (STP), a novel tryptamine analogue, on parameters of cell viability, oxidative stress, and immunomodulation in RAW 264.7 macrophages. Cell Biol Toxicol 29: 175-187.

GAUTAM R AND JACHAK SM. 2009. Recent developments in anti-inflammatory natural products. Med Res Rev 29: 767-820.

HAJARE SW, CHANDRA S, SHARMA J, TANDON SK, LAL J AND TELANG AG. 2001. Anti-inflammatory activity of Dalbergia sissoo leaves. Fitoterapia 72: 131139.

HIFNAWY MS, VAQUETTE J, SÉVENET T, POUSSET JL AND CAVÉ A. 1957. Produits neutres et alcalóides de Myrtopsis macrocarpa, M. myrtoidea, M. novaecaledoniae et M. sellingii. Phytochemistry 16: 1035-1039.

JASWIR I AND MONSUR HA. 2011. Anti-inflammatory compounds of macro algae origin: A review. J Med Plants Res 5: 7146-7154.

JIANG XL, SHEN HW AND YU AM. 2016. Modification of 5-methoxy-N,N-dimethyltryptamine-induced hyperactivity by monoamine oxidase A inhibitor harmaline in mice and the underlying serotonergic mechanisms. Pharmacol Rep 68: 608-615.

KAUSHIK NK. 2013. Biomedical importance of indoles. Molecules 6: 6620-6662.

METCALFE DD. 2008. Mast cells and mastocytosis. Blood 15: 946-956.

NARUM S, WESTERGREN T AND KLEMP M. 2014. Corticosteroids and risk of gastrointestinal bleeding: a systematic review and meta-analysis. BMJ Open 4: e004587.

NEEB L, HELLEN P, BOEHNKE C, HOFFMANN J, SCHUH-HOFER S, DIRNAGL U AND REUTER U. 2011. IL-1beta stimulates COX-2 dependent PGE (2) synthesis and CGRP release in rat trigeminal ganglia cells. PLoS ONE 6: e17360.

NORTON S. 1954. Quantitative determination of mast cell fragmentation by compound 48/80. Br J Pharmacol 9: 494497.
OECD. 2002. Test No. 423: Acute oral toxicity-Acute toxic class method. In: OECD Guidelines for the Testing of Chemicals, Section 4. OECD Publishing, Paris, http:// dx.doi.org/10.1787/9789264071001-en. Accessed July 21, 2016.

OLIVEIRA FA, ALMEIDA RN, SOUSA MF, BARBOSAFILHO JM, DINIZ AS AND MEDEIROS IA. 2001. Anticonvulsant properties of N-salicyloyltryptamine in mice. Pharmacol Biochem Behav 68: 199-202.

QUINTANS-JÚNIOR LJ ET AL. 2010. BioassayGuided Evaluation of Antinociceptive Effect of N-Salicyloyltryptamine: A Behavioral and Electrophysiological Approach. J Biomed Biotechnol 2010: 230745.

SÁ-ALVES FR, BARREIRO EJ AND FRAGA CA. 2009. From nature to drug discovery: the indole scaffold as a 'privileged structure'. Mini Rev Med Chem 9: 782-793.

SADEGHI H, HAJHASHEMI V, MINAIYAN M, MOVAHEDIAN A AND TALEBI A. 2013. Further studies on anti-inflammatory activity of maprotiline in carrageenan-induced paw edema in rat. Int Immunopharmacol 15: 505-510.

SCHRIPSEMA J, DAGNINO D AND GOSMANN G. 2004. Alcalóides indólicos. In: Simões CMO, Schenkel EP, Gosmann G, Mello JCP, Mentz LA AND Petrocick PR (org), Farmacognosia: da planta ao medicamento. $5^{\mathrm{a}}$ ed., Porto Alegre/Florianópolis: Editora da UFSC, p. 819-846.

SHEN HW, JIANG XL, WINTER JC AND YU AM. 2010. Psychedelic 5-methoxy-N,N-dimethyltryptamine: metabolism, pharmacokinetics, drug interactions, and pharmacological actions. Curr Drug Metab 11: 659-666.

SHERWOOD ER AND TOLIVER-KINSKY T. 2004. Mechanisms of the inflammatory response. Best Pract Res Clin Anaesthesiol 18: 385-405.

VENDRAMINI-COSTA DB AND CARVALHO JE. 2012. Molecular Link Mechanisms between Inflammation and Cancer. Curr Pharm Des 18: 3831-52.

WILLIAMS JE. 2001. Review of antiviral and immunomodulating properties of plants of the Peruvian Rainforest with a Particular Emphasis on Uña de Gato and Sangre de Grado. Altern Med Rev 6: 567-579.

WINTER CA, RISLEY EA AND NUSS GW. 1962. Carrageenin-induced edema in hind paw of the rats as an assay for anti-inflammatory drugs. Proc Soc Exp Biol Med 111: $544-547$.

YADAV UCS AND ROMANA KV. 2013. Regulation of NF$\kappa \mathrm{B}$-induced inflammatory signaling by lipid peroxidationderived aldehydes. Oxid Med Cell Longev 2013: 690545. 